\title{
INFLATION TARGETING EXPERIENCE: LESSONS FOR UKRAINE
}

\author{
David Vavra' \\ OG Research, Ltd.
}

\begin{abstract}
In the past three decades, many advanced market and emerging market economies have modernized their monetary policy frameworks. We research the experience of these economies for lessons relevant to the monetary policy in Ukraine, which has recently embarked on a similar modernization program. Most countries we study have adopted some form of inflation targeting, given unfavorable experiences with previous regimes based on money and exchange rate, however with the exchange rate continuing to play an important role. Most of the pillars of effective IT monetary policy developed over time through determined efforts led by central banks, and the initial conditions did not matter for success. Countries have experienced numerous challenges with regards to communication, credibility, policy transmission, and fiscal dominance. Overcoming these challenges gave rise to new practices, which now form the state-of-the art monetary policy, irrespective of whether it is called an IT regime. A general lesson for Ukraine (as well as other future modernizers and IT adopters) is that determination and speed in building the pillars of IT policy is paramount for success and credibility of the new framework.
\end{abstract}

JEL Codes: E58, E52

Keywords: inflation targeting, monetary policy, inflation targets

\section{Introduction}

In the past three decades, many advanced market ( $A M)$ and emerging market (EM) economies have modernized their monetary policy frameworks. Their experience during the modernization process offers valuable lessons for countries that are considering improving their own policy frameworks, such as recently Ukraine. In this study, we aim to consolidate the experience of previous transitions of monetary policy regimes by studying and summarizing the steps undergone, the challenges faced and the measures undertaken to overcome these challenges.

Such evidence, we hope, will provide useful inspiration for the Ukrainian authorities. The monetary policy in Ukraine is right now at a critical juncture of choosing a new nominal anchor for the future after floating the currency under pressure in 2014. The National Bank of Ukraine (NBU) has in the past two decades tried to achieve or contribute to a number of objective, including low inflation, stable and predictable exchange rate, sound financial and banking system, and sustainably growing economy.

There have always been good reasons for aiming at these various objectives. For instance, a stable value of the currency in a highly dollarized economy is an important anchor for public's expectations, guiding their production, saving and investment decisions. Volatile inflation hurts socially most vulnerable parts of the society, in addition to obscuring the real value of transactions, increasing uncertainty and inhibiting the investments by increasing risk premiums.

Unfortunately, the NBU has struggled in attaining any of these objectives. Inflation has fluctuated from minus 1 to more than 30 percent (excluding 2014, 2015 episodes) and growth rates varied from minus 15 to more than 12 percent. The exchange rate moved on several occasions, in the long-term changing its value more dramatically than many of the floating currencies during the same long-term period. The financial and banking system all but collapsed during in the aftermath of the global financial crisis. In the period up to the crisis, the dollarization of the economy was increasing continues to be significant.

${ }^{1}$ I thank Botir Khan and Bi Ran for helpful comments and discussions. 
It turns out that many of the countries included in this survey have shared a similar experience and were likewise struggling to find a way forward. Their experience could therefore usefully be considered by the monetary authority in Ukraine, when making the strategic choices for the forthcoming period.

We find that most countries, which have transitioned previously, have adopted some form of inflation targeting (IT), given unfavorable experiences with previous regimes. Before the start of the process, they targeted both money and exchange rate. Policy transparency and accountability were absent and almost nothing was known of transmission mechanisms. These countries have chosen inflation as the nominal anchor and the pace of transition depended on the timing as well as market conditions. Most of the pillars of effective monetary policy were developed over time and the initial conditions did not matter for success. Countries have experienced numerous challenges with regards to communication, credibility, policy transmission, and fiscal dominance.

The rest of the paper is organized as follows. The next section discusses the beginning of the modernization process, while the next sections concentrate on the process management, including the conditions that make the modern monetary framework effective, challenges during transition and the ways to tackle such challenges. Finally, we summarize the performance of IT countries and conclude.

\section{Why did these countries decide to change their frameworks?}

In general, the transition to more effective monetary policy frameworks was motivated by unfavorable experiences with nominal anchors in terms of the exchange rate and money, as well as a desire to lower the rate of inflation and to anchor inflation expectations through a simple observable target variable.

The initial frameworks would typically share some of the following features:

- Intermediate targets in terms of money and/or exchange rates. Typically the authorities would follow both the exchange rate and money targeting, which was certainly the case in most EMEs, but also in many developed economies (especially those in the EMS). Only some, especially developed economies such as US and Canada, would work only with monetary anchors.

- Operational framework based on base money or free reserves, occasionally interest rates. The EMEs would usually set volume based operation targets (with some exceptions, such as Israel), while the experience of the developed economies was more diverse and some used interest rate as operational targets (e.g. Canada and US).

- Unclear separation of monetary and fiscal policies. The concept of monetary policy autonomy was not clearly established de facto and often not even de jure. While some developed economies (US, Germany, Canada) had very independent central banks, elsewhere autonomy came more gradually. For instance, in Great Britain the de facto and de jure policy independence was only established in the second half of 1990s (Freedman and Laxton, 2009). Similar situation also existed in Columbia where the first inflation targets were announced in early 1990s by the Minister of Finance and no autonomy in the design and execution of monetary policy existed (Hamann et al., 2014). In many EMEs monetary policy often worked under the shadow of fiscal policy and political pressure to keep interest rates low to help contain rising public debt (and often also to finance politically important projects). This was also de facto the case in many transition EMEs, in which de jure central bank independence existed early on thanks to newly adopted central bank laws modeled on best practices (Batini and Laxton, 2006).

- Little policy transparency and accountability. Communication policy could loosely be characterized as keeping "the press out of the bank and the bank out of the press" (Blinder et al., 2008). In many cases this reflected the lack of autonomy or authority to conduct monetary policy by the central banks. In others, the opacity was given by the choice of monetary intermediate and operational targets, whose changes were difficult to communicate transparently, and also perhaps from a belief that surprise policy moves are more effective. Regular explanations of policy actions in inflation and monetary policy reports and press briefings would be unusual. ${ }^{2}$

${ }^{2}$ The term "Inflation Report" was coined by the Bank of England in mid 1990s as a compromise reflecting the fact that the Bank did not have the authority over monetary policy at the time 
- Little knowledge about monetary policy transmission mechanism and workings of the real economy. Only large developed economy central banks would have macroeconomic models with worked out transmission channels (often backward-looking) and invest in the macroeconomic analysis as a tool for policy guidance (Freedman and Laxton, 2009). Given the emphasis on monetary intermediate targets, monetary theories of inflation would play an important role in policy setting. Most analytical activities in EMEs would consist of liquidity forecasting and financial programming as a basis for setting the intermediate and operational targets (Capek et al., 2003).

In developed countries the main motivation for a change was the drive to reduce inflation (Canada, US) in the environment, in which money targets have lost their anchoring power and some countries lost the ability to keep fixed exchange rates under market pressure (UK) (Freedman and Laxton, 2009).

In EMEs the problems with previous regimes often stemmed from a pursuit of a number of different intermediate, as well as operational, targets (Otker-Robe and Vavra, 2005). The inconsistencies among these targets became exacerbated by rapid capital flow movements, as the international financial markets became more integrated and these countries had liberalized their capital accounts. The problems were especially acute in smaller EMEs, in which the pressure to sterilize capital flows put money supply out of control, putting pressure on the exchange rate and exacerbating internal imbalances (Columbia, Czech Republic, Hungary, Serbia).

In several EMEs the link between money and inflation was falling apart or monetary targeting (often under IMF tutelage) was considered to have contributed to unnecessarily deep recessions (Philippines). In others, the stability of monetary relationship provided an anchor, which companied the transition to a more effective policy framework for some time (Columbia, Indonesia).

In most cases (both EM and AEs) the transitions were orderly and gradual, while in a few others disorderly and under market pressure. In some cases they were planned arising from a conscious decision to transit to a different monetary anchor, elsewhere they just evolved from the previous regimes. For instance, in Israel, Columbia and Chile inflation targets were put in place initially to support crawling ER bands. In Romania and Hungary, they arose against the need to achieve inflation convergence of the EU integration criteria. In Canada, the transition to inflation reflected the need to anchor inflation expectations in face of specific shocks (Freedman and Otker-Robe, 2009).

Some countries started the process following a currency or general economic crisis (Czech Republic, Brazil, Indonesia, Thailand, and Uruguay). In other cases the process was better planned and individual steps were taken in a planned sequence (Poland, Israel, Chile). In some, we see both the crisis and plan elements together, with the crisis acting as a catalyst of a planned process (Turkey).

Some elements evolved independently, others were more sequenced. For instance, the intention to steer (a loose form of targeting) market interest rates, rather than set volume based operational targets derived from intermediate money targets, emerged very early in many of these countries, irrespective of the regime. On the other hand, changing the communication practices and increasing policy transparency took place in tandem with adopting inflation targeting regimes and strengthening the analytical frameworks.

In summary of the country experiences, it appears that the nature of the trigger did not matter for success. However, it affected the sequencing and speed of implementation of elements of more effective monetary policy. In particular, the crisis trigger transitions often forced accelerated development of inflation as an alternative anchor with all the supporting elements, although the sequencing would not always be as optimal and planned as in the economies transiting more gradually for other reasons than a crisis.

\section{What new frameworks did the countries choose, given their specific circumstances?}

Ultimately, most countries strengthening their policy frameworks ended up with some form of Inflation Targeting, however very few would qualify for what we label a "full-fledged" inflation targeting. Indeed, especially among the EMEs, the exchange rate has retained a "special status" until these days. In practically all countries it has remained an important instrument/ operational variable. In many it has not yet lost its role in anchoring expectations, although it ceased being an official intermediate target many years ago (Georgia, Serbia, Armenia, Russia). The latter is especially true for highly dollarized economies (Roger et al., 2009; Stone, 2003).

The exchange rate consideration played an important role in the choice of the intermediate target and nominal anchor. The choice of the countries without an exchange rate anchor, i.e. mostly advanced economies, was more deliberate and less constrained than those with an exchange rate anchor (most EMEs). Initially, these advanced economies chose inflation as the 
new anchor, considering it a better conduit to achieving price stability (New Zealand) and disinflation objectives (Canada) than monetary targets. Other advanced economy central banks (e.g. the FED and ECB) embraced the principles of inflation targeting following good experience of the early adopters.

For the countries, which had started off with an exchange rate anchor the choice of the intermediate target reflected closely the ability to deal with a fear to float and the speed of embracing exchange rate flexibility (Israel, Poland, Hungary). Ex rate targets often accompanied the transition process for many years and monetary variables to some extent too (ECB, Armenia, Uruguay).

During the transition process, the exchange rate (and to a lesser extent monetary targets) were being transformed from intermediate targets and anchors to important transmission variables and instruments. The process reflected a growing emphasis on reducing inflation as compared to other goals (e.g., competitiveness), as the long-term priorities for monetary policy shifted, but also the comfort the authorities would feel in understanding the analytics of an inflation-interest rate framework. Flexible exchange rates helped absorb the impact of the inflows and let the authorities set interest rates at levels consistent with inflation targets. Reduced implicit exchange rate guarantees also helped limit incentives for speculative inflows. This process was faster in countries, which exited from a fixed exchange rate arrangement abruptly and under stress (Czech Republic, UK).

The countries experiencing an exchange rate or balance of payments crisis would typically all choose inflation as the alternative target soon after the crisis, following monetary targets in the meantime. This is especially true of the transition EMEs, but also several developed economies would adopt inflation targeting soon after the collapse of their fixed exchange rate arrangement, e.g. UK or Spain. A direct focus on inflation seemed the only viable alternative to quickly establish credibility in these countries (Turkey, Czech Republic).

\section{How did they start the process and put conditions and the principles for and effective IT in place?}

In many cases the process of putting in place the elements of an effective IT policy framework evolved over long periods, sometimes lasting close to a decade. This is especially true for EMEs transiting to more modern policy frameworks in 1990s (Poland, Czech Republic, Brazil). The countries transiting in 2000s in general took less time to implement some of these elements, which may reflect both the fact that the state-of-the art was better known (than in 1990s) as well as the benefits of learning from the previous experience of the first wave countries. This is certainly the case of Serbia, Georgia and Moldova, which were able to put in place these elements very quickly, sometimes in a matter of months or only a few years.

Most theoretical literature studying conditions facilitating a transition towards more effective monetary policy frameworks examines the issue from the perspective of countries transiting to some form of inflation targeting (Carare et al. 2002, 2003, Batini et al., 2005). There are a number of different versions of conditions conducive to a smooth transition to modern monetary policy frameworks, and more specifically to IT. According to one classification (Batini et al., 2005) these are:

- institutional independence (full legal autonomy, lack of fiscal dominance, operational CB independence, fiscal balance,...);

- financial system health (capitalization of banks, stock and bond market development, FX mismatches, ...);

- well-developed technical infrastructure (data availability, systematic forecast process, models for conditional forecasts);

- economic structure (ER pass-through, dollarization, trade openness, sensitivity to commodity prices,...).

Other classifications tend to emphasize less the "exogenous processes", such as the financial system health and the economic structure, and sometimes bring in the initial macroeconomic balance as an additional consideration (Carare et al., 2002). In summary, the empirical literature finds overwhelmingly that no country transiting to Inflation Targeting had all elements considered useful for a smooth transition fully in place prior to IT adoption (Batini et al., 2005). Predictably industrial country ITers fared better in "fullfilling the conditions" at the start of their transition than emerging markets ITers (with Canada probably only one satisfying most of the conditions or coming close to it).

In particular, the future ITers had shared the following features at the beginning of their transitions:

- little or no forecasting capability and no forecasting model; EMs often had bad data;

- most scored poorly on financial and banking system health, but had a relatively favorable capital and open foreign currency positions; 
- most enjoyed some institutional independence in the form of lack of fiscal dominance and instrument independence, however legal independence was often circumscribed;

- many countries also kept a dual anchor (e.g. Hungary, Poland, Island). This is partly true also of the ECB, which (although not an ITer) pursues the principles of modern monetary policy and officially has followed both inflation as well as monetary aggregates;

- countries also scored poorly in terms of legal independence of the central bank and in having ineffective policy transmission dominated by the exchange rate channel.

As for the conditions that seemed to have been in place at the outset of the transition in a majority of countries and which the literature generally assumes as the critical set of conditions, which is good to have before the process of strengthening monetary policy framework can begin:

- inflation target, relatively generously defined (price stability mandate);

- central bank's control over its own balance sheet (while some other forms of fiscal dominance may have been present);

- instrument independence and certain effectiveness of its implementation;

- a functioning of spot FX market, and some financial system capacity to manage FX risk.

The IT country cases show that conditions make the transition easier, but are not a show stopper. More generally, many of these conditions are in fact characteristics of a well-functioning effective monetary policy regime. The process of putting them in place is therefore tantamount to making the new policy regime more effective and credible.

In general, it appears that not having all the desirable arrangements in place at the outset of the transition process is not an impediment to the performance of the regime. Literature shows that "Preconditions" do not make much difference in explaining the improvement in macroeconomic performance in terms of inflation, output growth and their variability under IT (Freedman and Otker-Robe, 2010). It appears that it was more the resolve and speed of implementing the conditions rather than their initial level, which mattered for the performance of the regimes. Indeed, in many countries adopting an inflation targeting regime, it appears the causality ran from the adoption of an IT regime to the satisfaction of the supporting conditions rather than the other way round.

The literature also finds that the improvements in the conditions achieved by the transiting countries (notably in technical infrastructure) significantly outpaced the speed of similar developments in non-transiting countries (Batini and Laxton, 2006). This lends credence to the assertion that the resolve to transit has a positive effect on the speed of the adjustment (Freedman and Otker-Robe, 2010).

\section{How did they manage the transition/modernization process?}

Sequencing of the steps in building the elements of effective monetary policy was an important factor in the durability of the transition and the macroeconomic performance. Although establishing each element of effective monetary policy took often many years, in general the sequencing looked as follows:

- Basic elements of policy and instrument independence exist and the central bank has a control of its balance sheet. Although the fiscal position may be unsustainable and other forms of fiscal pressure exist, the central bank has enough autonomy to decide which instruments to use and authority to promote the financial market development.

- Some elements of interest rate targeting appear together with allowing for some exchange rate flexibility. Many countries understood quite early in the transition the benefits of interest-rate based policy and the necessity to allow for some exchange rate flexibility. The latter would often be triggered by operational practicalities, but soon would become a necessity given the desire to implement policy through changes in interest rates.

- Efforts to stimulate the development of financial markets (domestic debt market, FX spot and forward markets, sometimes FRA market) begin, sometimes in steps with financial account liberalization. Allowing for some exchange rate volatility would soon trigger the process of building FX markets and become a spur to FX risk management capacities. The second most important institutional element in this phase was the regular issuance of fungible government debt, without which the local currency yield curve could not develop, thus undermining the role of the interest rate transmission channel. The development of the FX derivative and FRA 
markets would also take place in some countries at this stage, putting pressure on the central bank to become more transparent about its policy course. ${ }^{3}$

- Exchange rate flexibility is gradually increased. Market pressure sometimes forces a fast exit, often in connection with liberalizing the capital flows. The forces of the impossible trinity and increased capital account liberalization gradually increase the need for more exchange rate flexibility. In the countries following simultaneously inflation and exchange rate targets, the conflicts between the two would require relaxing the exchange rate target. However, ideally the liberalization of the capital account would come in a well-planned sequenced (see later). The countries, which liberalized the capital markets too quickly (e.g. the Czech Republic in 1996 or Israel and Chile in 1970s) would become hostage to the volatility of the external financial flows, often triggering financial crises and disorderly exits from pegs (Czech Republic).

- Inflation as the alternative anchor is chosen and first targets announced, often for the short-term and sometimes coexisting with the exchange rate anchor. Inflation as the alternative anchor starts appearing in this stage either out of necessity after a crisis-driven exit from the peg, or out of considering alternatives for the increasingly looser exchange rate anchor.

- A broad monetary policy independence and autonomy (including the role in the exchange rate regime) is being established. The concepts of operational, financial and personal independence of the central banks are established and legally sanctioned. The central banks sometimes get the target autonomy (or share it with the government) and authority over the exchange rate regime. ${ }^{4}$

- Analytical capacities and communication strategy develop. After inflation is chosen as the alternative anchor, the central banks work on putting in place the necessary institutional elements, including more central bank independence, transparency and accountability, and analytical forecasting capacities. The latter would often take several years to develop.

- Medium-term inflation targets are announced and ex rate anchor is finally abandoned. The exchange rate often continues to play a more important role than a mere instrument or a transmission variable, leading to the development of a specific FX intervention strategy.

However, the evidence also shows that this particular sequencing was not ideal. In particular, earlier investments in communication and analytical capacities could have contributed to a smoother transition and faster build-up of credibility. For instance, the absence of the analytical capacities led to short policy horizons, increasing macroeconomic volatility and undermining the credibility of the process. In several cases, having adequate communication tools would have helped achieve a general public consensus on the transition process earlier. In that respect it also appears that the choice of inflation as the alternative anchor could have been made faster. ${ }^{5}$ Finally, the evidence also reasons against a premature financial account liberalization, which should in general follow (rather than precipitate) greater exchange rate flexibility.

In summary, an idealized sequence could look as follows:

- Inflation is chosen as the nominal anchor and communicated (at least in the form of a medium-term inflation target).

- Some elements of interest rate targeting appear together with allowing for some exchange rate flexibility. Efforts to stimulate the development of financial markets (domestic debt market, FX spot and forward markets, sometimes FRA market) begin.

- Exchange rate flexibility is gradually increased, followed by financial account liberalization.

- The market interest rate becomes the main operational variable, the role of reserve requirements and other instruments declines. Analytical capacities and communication strategy develop, focused on the setting of the key policy rate as the main instrument. The decision making process is being adjusted accordingly.

\footnotetext{
3 Allowing foreign investors to participate in the development of the financial markets was an important positive element in these developments, as they served as conduits of good standards, added market liquidity and provided transaction counterparties in otherwise one-sided markets.

4 The central banks of Mexico and the Czech Republic (for a certain period) have enjoyed full target autonomy, otherwise the cases of central bank's full target autonomy are relatively rare.

${ }^{5}$ Colombia's experience shows in particular the importance of announcing the target as a part of the new price stability framework. The failure to do so contributed to the extremely low credibility of the new anchor and framework (Gomez et al., 2002).
} 
- Annual or continuous inflation targets are announced (and not revised) and the exchange rate anchor is being suppressed (e.g. widening bands), but the exchange rate continues to play a more important role than a mere instrument or a transmission variable, leading to the development of a specific FX intervention strategy.

- The exchange rate anchor is finally abandoned and the exchange rate continues as a supporting instrument strengthening the transmission of the interest rate as the main instrument, when needed.

The central banks played a vital role in initiating, spearheading and managing the transition. They would initiate the dialogue with the governments, take an active approach in changing the legal environment, work with opinion groups and lead interagency task forces coordinating the steps in individual areas. They would also play a very important role in the financial market development by managing liberalization, promoting good standards and codes of conduct as well as helping to establish the market technical and legal infrastructure. In later stages they would enact regulatory measures promoting the development of the local currency markets and instruments, and reducing dollarization (Serbia, Georgia, Turkey, Peru, Russia and Moldova). In several countries, the central banks were the major force behind a regular T-bill issuance at benchmark maturities and sufficient volumes to facilitate the market development (Macedonia and Thailand).

\section{What challenges did they facing and how did they manage/ overcome them?}

\section{Perceived lack of credibility}

Much of the delays experienced during the transition were linked to a perceived lack of credibility of the new policy and anchor (Turkey). The capacity to forecast and hit inflation targets was considered low, and the authorities were wary of the effects target misses may have on the nascent regimes. In several cases, the initial inflation targets were missed by a wide margin, causing sometimes a public backlash at the central bank's strategy (especially when linked to a recession, as in the Czech Republic in 1999) and vindicating a more cautious approach in other countries. In other cases, also in the advanced economies, the fiscal situation was precarious, limiting the room for the monetary policy maneuvering and often causing overly high real interest rates and macroeconomic volatility (Brazil, Turkey, Canada, United States).

As a result of the perceived lack of credibility many countries tended to "over-prepare", sometimes waiting too long before they considered themselves well prepared and at an opportune moment. Sometimes, such a moment never came (Ukraine).

The fear of undermining the nascent regimes also advocated the focus on narrower inflation indices, typically ignoring the volatile components, such as foods, and regulated prices. At the same time, the central banks would work out an elaborate list of "escape clauses" exonerating them from meeting inflation targets under specific ex ante (or ex post) circumstances. The communication challenges involved were gargantual, and both strategies eventually backfired. Ignoring volatile foods may have resulted in better forecast accuracy, but hardly endeared the regime to the population, whose consensus was important for restoring credibility. The system of escape clauses obfuscated the workings of the regime, which should have been built on clarity and transparency. As such, most countries gradually switched to targeting headline inflation and abandoned escape clauses during in 2000 s.

Also for credibility reasons, the central banks would initially refrain from using long-term inflation targets before realizing the importance this has for anchoring expectations. Most EMEs would start with short-term inflation targets, sometimes revised every year (Indonesia, Ghana, Serbia). Some relatively established ITers would even revise their targets upwards in an effort to keep credibility in the face of durable shocks (Turkey, Brazil). However, these practices are generally not considered as credibility enhancing and most countries would gradually converge to relatively constant levels of medium-term inflation targets (SchmidtHebbel and Werner, 2002).

The fear of insufficient credibility was especially acute in countries, which had suffered a currency crisis forcing them off their pegs. The sharp exchange rate depreciation, the absence of an inflation anchor, and the memories of high inflation periods fueled fears of a return to hyperinflation. Some responded by hastening the adoption of a new regime, while the others by returning (at least temporarily) under the shelter of a monetary and exchange rate target (Uruguay, Czech Republic).

\section{Fiscal dominance}

Gaining de jure and de facto the control over its own balance sheet was one of the most important preconditions for the transition process to start (Freedman and Otker-Robe, 2010). However even with a control over the balance sheet, the room for effective monetary policy in macroeconomic stabilization remained limited, as long as it remained constrained by market fears about fiscal sustainability, external balance or both (Turkey, Brazil). 
These fears gave rise to various endogenous premiums, which limited the effectiveness of monetary policy actions. For instance, an increase in interest rates in response to an inflation shock would provoke an increase in the currency premium for a fear of effects on fiscal sustainability (Ghana, Serbia). Likewise, an effort to stimulate economy by cutting rates may backfire, when the external balance is hit by a rapid capital outflow (such as in many Latin American external crises of the past). Fearing such outcomes, the monetary authority's reaction in many cases would have been muted. The "fear of float" is one of the most prominent examples of such concerns, which would slow the transition process (Schmidt-Hebbel and Werner, 2002; Ramos-Francia and Garcia, 2005). However, even the experience of industrialized countries, such as Canada in early 1990 s or US in early 1980 s shows how real interest rates were unnecessarily pushed up by a lack of support of fiscal policy to disinflation (Freedman and Otker-Robe, 2010).

Such considerations sometimes gave credence to arguments that, in addition to eliminating fiscal dominance, a country should have a sound fiscal position before the start of a process of implementing inflation targets (Carare et al., 2002; Masson et al., 1998). In fact, the evidence from industrialized as well as some EMEs shows that the adoption of more effective monetary policy preceded structural improvements in fiscal policies or went hand in hand (e.g. Columbia) (Tapsoba, 2010). Interestingly, Batini et al. (2005) examining a sample of 13 EMEs, finds the fiscal position before inflation targeting adoption or the absence of fiscal improvement after adoption does not seem to affect the regime's ability to deliver lower and stable inflation.

The experience of Israel is particularly interesting in this respect, as there seems to have been a positive feedback-loop from the benefits of a forward-looking monetary regime to fiscal discipline. The IT regime facilitated the development and lengthening of the yield curve, which in turn paved way for the development of local currency mortgage market. The mortgage market, affecting the majority of population, is particularly sensitive to fiscal policy, which thus became more disciplined for political reasons. According to some observers, it is not a mere coincidence that political cycles ceased to an issue in Israel around the time, when the IT gained credibility.

\section{Ineffective policy transmission}

An ineffective policy transmission (factual or perceived) dominated by the exchange rate channel in the environment of underdeveloped and dollarized financial markets and significant extent of price regulation would exacerbate the credibility problems, especially in the emerging market economies.

The policy transmission was often deemed dominated by the exchange rate channel (also in some AEs, such as New Zealand). Indeed, the exchange rate pass-through to inflation and sometimes to output (via exports) was very strong in the initial transition stages in most (and especially small open) economies. Further complication would often arise from a significant portion of regulated prices in the CPI basket, sometimes prompting the central banks to target narrower price indices - a strategy that would later found unproductive and abandoned.

The absence of domestic financial markets was further limiting the use of the interest rate policy. Financial stability issues of unhedged FX positions of private and public sector balance sheets advised caution vis-à-vis abrupt exchange rate changes. For instance, in Hungary in between 2008 and 2013 around two-third of household loans were denominated in the Swiss franc and FX loans were also widespread among SMEs. The central bank was afraid of the vicious circle (experienced also during the South-East Asian crisis in 1997-1998), when a sharp exchange rate weakening led to increase in default rate of $\mathrm{FX}$ borrowers turning the balance of payments crisis into a banking crisis. Therefore, in addition to inflation targeting monetary policy attached high importance to exchange rate level implicitly in its decision making and communication. This only changed after 2013 after housing FX loans were administratively converted into the local currency.

However, a gradual build-up of the pillars of modern monetary policy was found to be rapidly changing the transmission process. Indeed, according to many studies the exchange rate pass-through has declined substantially in a vast majority of IT countries over time (Baqueiro and others, 2003; Coulibaly and Kempf, 2010). This was a result of a strengthened policy framework with more systematic and predictable policies as well as a product of efforts to build stronger domestic financial markets and reduce dollarization (Chailloux et al., 2010).

The central banks played an important role in the process of creating and strengthening domestic financial markets. In the early transition stages they played a key role in setting standards of market based transactions in money and FX markets, promoting unification of trading platforms, instituting master repo agreements, promoting the establishing of the reference rates and market infrastructure in general. In later stages they would enact regulatory measures promoting the development of the local currency markets and instruments and reducing dollarization (Serbia, Georgia, Turkey, Russia, Moldova). Some of them would embark on dedicated campaigns of reducing dollarization (Hungary, Serbia, Georgia). 
In several countries, the central banks also played an important role in convincing the governments to start issuing domestic debt at benchmark maturities with adequate volumes - a key condition for the development of local currency markets.

Strengthening policy transparency through external communication has also been found instrumental in overcoming the issues with credibility and policy transmission. The efforts to increase accountability and transparency through regular communication events, such as Inflation Reports and press events, became a ubiquitous part of a monetary policy toolkit, gradually strengthening the credibility of the new regimes.

These efforts were guided by the objective of improving the predictability of the key policy rate as the benchmark rate in the local money market. The central banks working on policy transparency learned over time that admitting to own mistakes can foster the accountability and improve the credibility of its policy strategy. At the end of the day, it mattered more that the markets could well understand how the central bank will behave under particular circumstances and when it realizes its mistake.

The key elements of this communication approach involved: i) communicating that inflation forecast always goes to target eventually but with uncertainty, which does not explode over time, ii) communicating (verbally or explicitly) the expected future trajectory of the key policy rate, iii) holding regular (quarterly) meetings with financial market analysts, (iv) strengthening the role of the inflation report as the main communication vehicle and making it more forward looking, and (v) establishing a firm cycle of communication events following each policy decision making meeting according to a pre-announced calendar (such as, decision press release, press-conference, minutes, Inflation Report, events with specific audiences and journal articles).

If successful, such communication a cycles and elements would help make policy predictable by communicating policy preferences and future policy actions, and, in this manner, giving a fair idea of the policy reaction function. At the same time, the communication initiatives were instrumental in receiving a useful feedback, and also helping to improve the analytical apparatus.

While in the past the central bank's communication channels would mostly be used as a source of data, during the transition the emphasis began to be put on the text explaining the policy actions in terms of the objectives, explaining the mistakes and outlining the strategy of achieving the objectives in the future. The texts would evolve from large compendia (100+pages) of essentially statistical descriptions to relatively short, forward-looking messages, using plain language, with policy accountability and predictability as the main objectives. The Inflation Report in particular became the main vehicle in regular policy communication, emphasizing the target performance and providing a fair idea of a future policy course under particular circumstances.

Launching such a broad communication strategy would often also put extra pressure on good coordination of the many communication channels to achieve consistency and avoid over-communication. It would often require more resources in the communication departments and streamlining their organizational underpinnings. While before the transition many banks would feature just a press-service unit in the Governor's secretariat and a spokesperson, in the end the communication activities would typically concentrate in one department directly subordinated to the Governor.

\section{Multiple objectives and targets revisions}

For countries gradually abandoning the exchange rate anchor, the simultaneous pursuit of multiple objectives, especially the exchange rate and inflation, was a major challenge (Hungary). While such a situation was relatively manageable under closed capital accounts and in a slow growth environment, rapid capital flows tested the consistency of the regime soon after the local financial markets have been liberalized and/or more integrated into the world financial markets.

The experience of many countries shows that it is important to distinguish between the exchange rate as an additional intermediate target (in addition to inflation) and as an instrument of achieving an inflation target (and/or other objectives). While the former practice was not sustainable in the long-term and was difficult to manage, the latter continues to be practiced by many EM and AEs and gained special importance in the wake of the financial crisis.

During the transition process almost all EMEs experienced periods of two explicit intermediate targets: inflation and the exchange rate (Poland, Israel, Chile, Hungary). This practice would eventually lead to conflicts among these two targets. Those countries, which speedily sought to resolve these conflicts in favor of inflation (such as Israel and Poland) would see a gradual abandoning of the explicit exchange rate targets in a relatively smooth transition process. The countries, in which the priority would not be clear or fluctuate over time (such as Hungary or Chile in the early transition period), would face difficulties in establishing the regime's credibility. For instance, Chile was initially using past inflation rather than the inflation target in setting the rate exchange rate crawl, making the inflation targets almost impossible to achieve in the long-term term. In Hungary, monetary policy would occasionally loosen policy in order to defend the exchange rate band, while inflation was well above the target, eventually forcing an abandonment of the exchange rate bands. 
A related challenge was the management of implicit exchange rate targets, either factual or perceived. In many EMEs transiting to flexible exchange rate regimes, the exchange rate remained an important implicit target variable - or was perceived such by the markets and the public. This would enormously compromise the regime's credibility. The countries affected included Turkey (before the full-fledged IT was adopted in 2005), Russia, Georgia and Serbia among others. In many countries, the interventions against "excessive exchange rate volatility" would also fall under this category and would often be misused for affecting the exchange rate levels and thus further undermine the credibility of inflation as the new durable anchor.

Even when the exchange rate anchor was durably abandoned, many countries struggled in finding the right role for the exchange rate during and after the transition. The exchange rate often remained more than "a normal transmission variable", which deserves little more than casual monitoring. Many countries continued to intervene in the markets frequently, others labored over complicated intervention strategies in an effort to make their involvement in the FX market transparent.

Out of this struggle, two strategies emerged. One sought a refuge in austerity limiting its discretion to establish "credibility through principles" (Czech Republic). In others, discretion was encouraged as a way of dealing with practical short-term issues, which could have otherwise thwarted the modernization efforts (Georgia, Serbia). This eclectic approach saw the establishment of various forms of "light" IT regimes (Stone, 2003), not as a stepping stone to a full-fledged IT, but as a goal in itself (Goldstein, 2002; Freedman and Otker-Robe, 2010). Such an approach is typically characterized by having an explicit inflation target, FX interventions to smooth market movements, but not fighting fundamental shifts, and no FX targets. The interest rate policy is primarily used to target inflation, but on the margin the exchange rate consideration is also important.

On the other hand, the exchange rate remained as an instrument also in the arsenal of relatively well established full-fledged IT central banks - even if rarely used. For instance, Poland, the Czech Republic and Israel abandoned foreign exchange interventions for many years, but reactivated them again during and after the financial crisis as a supporting tool to interest rates in achieving the inflation target and restoring the economy to growth. So did Switzerland.

While for these economies, the recourse to interventions was communicated as temporary, a few other countries subscribe to these practices as a long-term strategy. For instance, Columbia works on the assumption that the interest and exchange rate instruments work through different transmission channels and thus monetary policy can be more effective when both are combined. Similarly, Israel applied two instruments with two objectives strategy for a while during 2008 and 2009.

However, these practices seem to differ from the long-standing "golden rule" of using FX interventions in IT regimes, i.e. to use the interventions in the same direction and after the interest rate moves (Holub, 2004). The main challenge in this approach is to communicate the difference between using the exchange rate as a target and an instrument, and how to execute and exit from a durable exchange rate intervention program. The Czech Republic was relatively successful by making sure the execution fulfills all the elements of Inflation Targeting, while some other central banks (Switzerland, Israel) faced considerable difficulties, perhaps owing to communication inconsistencies and unclear role of the interventions in the regime.

Another recently prominent policy issue is the coordination of monetary and financial stability policies. Various financial stability issues, including the quantity of money and asset prices, interact with monetary policy and may require a specific policy action, which may not always coincide with the desired monetary policy stance. For instance, very low inflation is likely to lead to low interest rates, which may exacerbate the financial sector imbalances and precipitate asset price bubbles.

While financial stability is a relatively new field, gaining prominence in the aftermath of the global financial crisis, the experience of many emerging market economies demonstrates that financial stability concerns should not come at the expense of undermining the primacy of the medium-term inflation objective. Any significant erosion of the central bank's credibility can unhinge inflationary expectations, with related undesirable effects on real activity and financial stability. What is crucial is to maintain a clear hierarchy of objectives with price stability being the primary objective. When price stability credibility becomes entrenched, the monetary authority gains more room to meet other objectives while not impairing price stability. Moreover, the experience shows that monetary policy is a blunt and relatively ineffective instrument for promoting financial stability. Instead, macroprudential tools should serve as the first line of defense in mitigating emerging financial imbalances, and monetary policy adjustments should only be deployed as a last resort.

Indeed, over the long-term financial stability concerns are generally complementary to the goal of price stability. For instance, a focus on inflation objectives with a credibly flexible exchange rate helps the development of financial markets by making the short term interest rate trajectory more predictable and therefore useful for pricing of longer-term financial instruments in the domestic currency. It also reduces incentives for saving and pricing in a foreign currency, thus reducing the dollarization of the economy, FX currency mismatches on private and corporate balance sheets. Especially in the EM context, the focus on price stability increases the resilience of the financial sector to swings in the exchange rate and capital flows. 
The experience of many LA countries illuminates especially well the importance of prioritizing the inflation stability objective and building capacities in being able to better manage the trade-offs among various objectives. Historically, external crises in the region were usually accompanied by muted and ambivalent monetary policy reactions and often by policy tightening for the fear of currency depreciation and the effects on dollarized balance sheets. The rigidities in the exchange rate regimes provided implicit guarantees to building up FX mismatched positions in the private sector, in turn aggravating the fear of float.

Refocusing policy on an inflation objective accompanied by intensive capacity building during 1990s and 2000s have made many of the LA economies and central banks more resilient to external shocks. During the latest financial crisis, LA central banks were able to cut interest rates to historic lows for extended periods and large exchange rate depreciation helped fight the external shock without engineering bouts of exchange rate speculation as in the past (de Gregorio, 2013). This was a product of strengthening the pillars of effective monetary policy in the recent decades, in particular the focus on price stability, flexible exchange rate and building more resilient financial markets with a capacity to hedge FX exposures. These policies, backed up by strong FX reserve buffers, became credible tools by the time the crisis struck.

\section{Looking at their performances after the transition, are there successful cases or failures that can be identified?}

The general evidence about the performance of IT-like countries across a number of criteria is very favorable, especially among the EMEs, both when examined over a longer period of time as well as during selected historical episodes (Roger, 2010; Batini et al., 2005). In AEs, on the other hand, the effects are generally small and insignificant (Roger, 2010; Ball and Sheridan, 2005; Goncalves and Salles, 2008), suggesting that establishing effective monetary policy frameworks may have greater benefits in less developed economies.

The long-term effects on reducing inflation, inflation and output volatility are significant and robust in most EMEs. Sometimes the benefits in terms of fast disinflation and reduced inflation volatility (without jeopardizing growth) appeared soon after inflation targeting was established (Turkey, Thailand, Indonesia to some extent), elsewhere it came over longer periods.

The IT regimes are especially credited for bringing about durable disinflation, sometimes on a spectacular scale (Turkey). For instance, Batini et al. (2005) surveying a sample of 13 EMEs finds the IT associate with 4.8 point reduction in average inflation, and 3.6 against the alternative regimes. While some of this may be attributable to the great moderation period in general, there seems to be evidence that the disinflation process in IT-like EMEs was independent of this. Inflation expectations declined too, and so did volatility of the exchange rate and the real interest rate (Levin, Natulucci and Piger, 2004).

At the same time, this reduction in inflation does not appear to have come at the expense of output stabilization. The IT-like countries were also found to be better able to fight both high inflation and deflation, reacting earlier and being less prone to boom-bust cycles and financial crises (probably thanks to more flexible exchange rate regime).

Some attribute the difference between the empirically observed benefits of IT in EM and AEs to the change in the credibility that accompanied the transition. While the AE central banks initially started off with a relatively high credibility stock, much of the efforts of the EME central banks during the transition focused on establishing it. This could also perhaps explain why the initial extent of satisfying various conditions mattered little for the overall success of these regimes (Batini at al., 2005).

\section{Food and Oil price shock}

As many of the EMEs countries started their transition in late 1990s, the food and oil price shock of 2007/8 was the first significant common global shock affecting most of the new regimes symmetrically at the same time. The evidence overwhelmingly shows that IT countries managed the shocks better than non-ITers (Habermeir et al., 2009). In general, they reacted faster to the shock and experienced lower inflation increase, although the targets were frequently missed.

The IT central banks understood the nature of the shocks, which allowed them to react faster and more decisively, and also enact policy easing before the shock completely subsided (Czech Republic). Also inflation expectations were found to be better anchored and resilient to the shock among ITers (Czech Republic) than non-IT countries. Among various measures used to contain the shocks, the interest rate based response of ITers was found to be more effective than administrative measures often applied by other countries.

Nevertheless, the shock posed a formidable communication challenge in many IT countries and several were not well prepared to sustain the pressures -- especially those in which the credibility of the regime had not yet been entrenched at the time. As a result, some responded with a target revision (Turkey), in others the process of establishing a full-fledged IT stalled, as the credibility was compromised (Serbia, Armenia). In Ghana the nascent IT regime fell apart during this period. 


\section{Financial Crisis}

The results from the financial crisis are also encouraging in that they show convincingly that the central banks embracing the principles of effective monetary policy gained more flexibility in responding to shocks.

The IT and flexible exchange rate regimes were able to leverage their monetary policy instruments and the flexible exchange rate to combat the crisis more effectively than others. In particular, ITers were able to reduce interest rates more than non-ITers and achieve more effective real policy easing than non-ITers, also because the inflation expectations were better anchored (de Carvalho Filho, 2010). This was especially true of the Latin American countries, where the clear and resolute response to the crisis marked a break from the muted reactions to similar events in the past, when the fear of capital outflows and other credibility concerns dominated the policy reactions. Unlike in the past, no significant adverse risk premium reactions occurred in most of the IT LA countries. The same was true of many Eastern European ITers.

The effects of monetary policy reactions to the crisis on employment and growth are less convincing, though. In part, this is perhaps because the ITers generally tended to have higher rates in the previous boom cycle than non-ITers and thus were better positioned to smooth the slump out. Nevertheless, there appears to be some evidence that the rebound from the crisis was quicker among IT countries and especially so among EM ITers, suggesting that good monetary policy can be more effective in relatively less developed economies.

Some economies were also able to use the credibility they had accumulated previously in designing unorthodox policies to fight deflation (e.g. the Czech Republic using FX commitment, UK). However, other ITers had to seek external assistance (Hungary, Romania, Serbia, Iceland) and in certain cases the regime was not resilient enough to the combined pressure of the world crisis and not yet entrenched credibility (Serbia, Iceland).

\section{The experience of Low and Low-to-Middle-Income Countries (LLMICs)}

The experience of the few LLMICs embracing IT policy principles is mixed. While Albania, Georgia and Moldova have managed to maintain their new regimes under relatively difficult circumstances of the world financial crisis and domestic political struggles, Ghana's progress stalled under fiscal dominance and too much policy discretion applied in the face of inflation shocks, which circumscribed the credibility of the nascent IT regime.

Armenia is pursuing a very eclectic regime featuring the exchange rate and money targets alongside inflation objectives, and the credibility of the regime is not yet entrenched, although it has fared well in the difficult environment of recent years. The exchange rate is an important instrument in the IT regimes of Georgia and Moldova too.

\section{Conclusion}

In the past three decades, many advanced market and emerging market economies have modernized their monetary policy frameworks. We study their motivations, experiences, challenges and factors contributing to success in order to draw common lessons useful for the monetary authorities in Ukraine, which are working to make their monetary framework more effective.

Most countries we study have adopted some form of inflation targeting, given unfavorable experiences with previous regimes based on money and exchange rate, both as intermediate targets and in an operational sense. These countries have chosen inflation as the nominal anchor with the exchange rate continuing to play an important role. Most of the pillars of effective IT monetary policy developed over time through determined efforts led by central banks, and the initial conditions did not matter for success. Countries have experienced numerous challenges with regards to communication, credibility, policy transmission, and fiscal dominance. Overcoming these challenges gave rise to new practices, which now form the state-of-the art monetary policy.

A general lesson for Ukraine (as well as other future modernizers and IT adopters) emerges in that determination and resolve in building the pillars of IT policy is paramount for success and credibility of the new framework. The experiences also show that, if the transition is managed well and proceeds speedily, larger benefits accrue more quickly to relatively less advanced economies with fewer initial conditions for success.

This article has been produced with the financial assistance of the European Neighbourhood Investment Facility.

The views expressed herein are those of the author and can therefore in no way be taken to reflect the official opinion of the European Union. 


\section{References}

- Armas A., Grippa F. (2005). Targeting Inflation in a Dollarized Economy: The Peruvian Experience. Working Paper, No. 448, IDB.

- Ball L., Sheridan N. (2005). Does Inflation Targeting Matter? In: Bernanke B., Woodford, M. (Eds), the inflation targeting debate. The University of Chicago Press: Chicago, pp. 249-276.

- Baqueiro A., de Leon A., Torres A. (2003). Fear of Floating of fear of Inflation? The Role of the Exchange Rate PassThrough in Monetary Policy in a Changing Environment. BIS Papers, No. 19, pp. 338-354.

- Barajas A., Steiner R., Villar L., Pabon C. (2014). Inflation Targeting in Latin America. Working Paper, No. 473, IDB. https://doi.org/10.2139/ssrn.2377644

- Barran F. (2005). Uruguay's Disorderly Exit from Peg to Float. IMF Mimeo.

- Batini N., Kuttner K., Laxton D. (2005). Does Inflation Targeting Work in Emerging Markets? World Economic Outlook, Chapter 4, IMF.

- Batini N., Laxton D. (2006). Under What Conditions Can Inflation Targeting Be Adopted? The Experience of Emerging Markets. Working Paper No. 406, Central Bank of Chile.

- Benes J., Berg A, Portillo R., Vavra D. (2014). Modeling Sterilized Interventions and Balance Sheet Effects of Monetary Policy in a New-Keynesian Framework. Open Economics Review, Vol. 26, No. 1, pp. 81-108.

- Blinder A. (1998). Central Banking in Theory and Practice, MIT Press, Cambridge MA.

- Blinder A., Ehrmann M., Fratzscher M., De Haan J., Jansen D-J. (2008). Central Bank Communication and Monetary Policy: A Survey of Theory and Evidence. Working Paper, No. 13932, NBER. https://doi.org/10.3386/w13932

- Capek A., Hledik T., Kotlan V., Polak S., Vavra D. (2003). Historical Perspective on the Development of the Forecasting and Policy Analysis System. Coats, Laxton and Rose (eds.): The Czech National Bank's Forecasting and Policy Analysis System, CNB, Prague.

- Carare A., Schaechter A., Stone M., Zelmer M. (2002). Establishing Initial Conditions in Support of Inflation Targeting, Working Paper, No. 02-102, IMF.

- Carare A., Stone M.R. (2003). Inflation Targeting Regimes. Working Paper, No. 03-9, IMF.

https://doi.org/10.5089/9781451842616.001

- Casta-eda J.C., Castillo C.E. (2005). Supply Shocks in the Transition Towards an Inflation Targeting Reform: An Empirical Evidence for Guatemala. Working Paper, No. 354, Central Bank of Chile.

- Central Bank of Brazil (1999). Monetary policy operating procedures in Brazil. Policy Paper, No. 5, BIS.

- Chailloux A., Ohnsorge F., Vavra D. (2010). Euroization in Serbia. Working Paper Series, No. 2010-120, EBRD.

- Corbo V., Schmidt-Hebbel K. (2001). Inflation Targeting in Latin America. Working Paper No. 105, Central Bank of Chile.

- Coulibaly D., Kempf H. (2010). Does Inflation Targeting Decrease Exchange Rate Pass-through in Emerging Countries? Working papers, No. 303, Banque de France.

- de Carvalho Filho I.E. (2010). Inflation Targeting and the Crisis: An Empirical Assessment. Working Paper, No. 45, IMF. https://doi.org/10.5089/9781451963045.001

- de Gregorio, J. (2013). Resilience in Latin America: Lessons from Macroeconomic Management and Financial Policies. Working Paper, No. 13-259, IMF. https://doi.org/10.5089/9781475550214.001

- Debelle G., Lim G.C. (1998). Preliminary Considerations of an Inflation Targeting Framework for the Philippines. Working Paper, No. 98-39, IMF.

- Duttagupta R., Fernandez G., Karacadag C. (2004). From Fixed to Float: Operational Aspects of Moving Toward Exchange Rate Flexibility. Working Paper, No. 04-126, IMF.

- Eichengreen B., Hausmann R. (1999). Exchange Rates and Financial Fragility. Working Paper Series, No. 7418, NBER. https://doi.org/10.3386/w7418

- Elberg A., Corbo V., Tessada J. (1999). Monetary Policy in Latin America: Underpinnings and Procedures. Cuadernos de Economia, Vol. 109, pp. 897-927.

- Fane G. (2005). Post-crisis Monetary and Exchange Rate Policies in Indonesia, Malaysia and Thailand. Bulletin of Indonesian Economic Studies, Vol. 41, Issue 2, pp. 175-195. https://doi.org/10.1080/00074910500117024

- Freedman C., Lexton D. (2009). Why Inflation Targeting? Working Paper, No. 09-86, IMF. 
- Freedman C., Ötker-Robe I. (2009). Country Experiences with the Introduction and Implementation of Inflation Targeting. Working Paper, No. 09-161, IMF.

- Freedman C., Ötker-Robe I. (2010). Important Elements for Inflation Targeting for Emerging Economies. Working Paper, No. 10-113, IMF.

- Galindo L.M., Ros J. (2006). Alternatives to inflation targeting in Mexico. Available at:

http://www.networkideas.org/feathm/oct2007/pdf/Galindo_Ros.pdf

- Gemayel E.R., Jahan S., Peter A. (2011). What Can Low-Income Countries Expect from Adopting Inflation Targeting? Working Paper, No. 11-276, IMF.

- Goldstein M. (2002). Managed Floating Plus. Institute for International Economics, Policy Analyses in International Economics, No. 66. Washington, D.C.

- Gómez, J., Uribe J.D., Vargas H. (2002). The Implementation of Inflation Targeting in Colombia. Available at: http://banrep.gov.co/docum/ftp/borra202.pdf

- Gonçalves C.E.S., Salles J.M. (2008). Inflation targeting in emerging economies: What do the data say? Journal of Development Economics, Vol. 85, pp. 312-318.

- Gurkaynak R.S., Sack B.P., Swanson E.T. (2004). Do Actions Speak Louder Than Words? The Response of Asset Prices to Monetary Policy Actions and Statements. Working Paper, No. 2004-66, FEDS. https://doi.org/10.2139/ssrn.633281

- Habermeier K., Ötker-Robe I., Jacome L., Giustiniani A., Ishi K., Vavra D., Kışınbay T., Vazquez F. (2009). Inflation Pressures and Monetary Policy Options in Emerging and Developing Countries: A Cross Regional Perspective. Working Paper, No. 1, IMF.

- Hamann F., Hofstetter M., Urrutia M. (2014). Inflation Targeting in Colombia, 2002-2012. Working Paper Series, No. 487 , IDB.

- Hammond G. (2012). State of the Art of Inflation Targeting - 2012. Centre for Central Banking Studies, Bank of England, Handbook No. 29.

- Holub T. (2004). Foreign Exchange Interventions under Inflation Targeting: The Czech Experience. Research and Policy Notes, No. 2004-01, Czech National Bank, Research Department.

- Hurnik J., Tuma Z., Vavra D. (2010). The Czech Republic on Its Way to the Euro: A Stabilization Role of Monetary Policy Revisited. Available at: https://www.elgaronline.com/view/9781849804363.00013.xml

- Hurnik J., Tuma Z., Vavra D. (2010). The Euro Adoption Debate Revisited: The Czech Case. Czech Journal of Economics and Finance, Vol. 60, No 3, pp. 194-212.

- International Monetary Fund (2005). World economic Outlook (Washington, September).

- Josifidis K., Pucar E.B., Srdic S., Ivan G. (2014). Inflation Targeting in Advanced vs. Emerging Economies before and after the Crisis. Panoeconomicus, Vol. 1, Special Issue, pp. 79-106.

- Kubo, A. (2009). Monetary targeting and inflation: Evidence from Indonesia's post-crisis experience. Economics Bulletin, Vol. 29, No.3, pp. 1805-1813.

- Lamberte M.B. (2002). Central Banking in the Philippines: Then, Now and the Future. Discussion Paper Series, No. 2002-10, PIDS.

- Levin A.T., Natalucci F.M., Piger J. (2004). Explicit inflation objectives and macroeconomic outcomes. Working Paper Series, No. 0383, European Central Bank.

- Lim J. (2006). Philippine Monetary Policy: A Critical Assessment and Search for Alternatives. Available at: http://www.peri.umass.edu/fileadmin/pdf/inflation/lim_paper10.pdf

- Martínez G.O. (2008). Inflation Targeting. Available at:

http://www.imf.org/external/np/seminars/eng/2011/res/pdf/go2.pdf

- Masson P.R., Savastano M.A., Sharma S. (1998). Can Inflation Targeting Be a Framework for Monetary Policy in Developing Countries? Finance and Development, Vol. 35, pp. 34-37.

- McLeod R. (2002). Toward Improved Monetary Policy in Indonesia. Australian National University, Arndt-Corden Department of Economics, Departmental Working Paper, No. 10.

- Medina Cas S., Carrión-Menéndez A., Frantischek F. (2011). Improving the Monetary Policy Frameworks in Central America. Working Paper, No. 11-245, IMF.

- Minelli A. (2005). Transition to a Floating Exchange Rate Regime: The Brazilian Experience. IMF Mimeo.

- Mishkin F.S. (2004). Can Inflation Targeting Work in Emerging Market Countries? Working Paper, No. 10646, NBER.

https://doi.org/10.3386/w10646 
- Mishkin F.S., Schmidt-Hebbel K. (2006). Monetary Policy under Inflation Targeting: An Introduction. Working Paper, No. 396, Central Bank of Chile.

- Mishkin F.S., Schmidt-Hebbel K. (2007). Does Inflation Targeting Make a Difference? Monetary Policy under Inflation Targeting, Vol. XI, edited by F. Mishkin and K. Schmidt-Hebbel, Banco Central de Chile, pp. 291-372.

- Nowotny E., Mooslechner P., Ritzberger-Grunwald D. (2010). The Euro and Economic Stability: Focus on Central, Eastern and South-Eastern Europe, Edward Elgar, Cheltenham UK. https://doi.org/10.4337/9781849805698

- Ostry J.D., Ghosh A.R., Chamon M. (2012). Two Targets, Two Instruments: Monetary and Exchange Rate Policies in Emerging Market Economies. Staff Discussion Note, No. 12-01, IMF. https://doi.org/10.5089/9781475503623.006

- Ötker-Robe I., Polanski, Z., Topf, B., Vavra, D. (2007). Dealing with Capital Inflows: Experiences of Selected European Countries. Working Paper, No. 07-190, IMF.

- Ötker-Robe I., Vavra D. (2005). Country Experiences with Moving To Greater Exchange Rate Flexibility: Operational Aspects. Occasional Papers, No. 256, IMF.

- Parkin M. (2014). The Effects of Central Bank Independence and Inflation Targeting on Macroeconomic Performance: Evidence from Natural Experiments. Review of Economic Analysis, Vol. 6, pp. 1-35.

- Polański Z. (2005). Poland's Experience in Dealing with Capital Inflows: Policies, Challenges and Effectiveness of Measures. IMF Mimeo.

- Polański Z., Szpunar P. (2005). Poland's Gradual and Orderly Exit to Exchange Rate Flexibility: Pace, Sequencing and Challenges. IMF Mimeo.

- Poon W.C., Lee Y.S. (2014). Inflation Targeting In Asean-10. South African Journal of Economics, Vol. 82, Issue 1, pp. 141-157.

- Psalida L.E., Elsenburg W., Jobst A., Masaki K., Nowak S. (2009). Market Interventions During the Financial Crisis: How Effective and How to Disengage? Global Financial Stability Report, Chapter 3.

- Ramos-Francia M., García A.T. (2005). Reducing Inflation through Inflation Targeting: The Mexican Experience. Working Paper, No. 2005-01, Banco de México. https://doi.org/10.1007/3-540-28201-7_1

- Reichlin L., Baldwin R. (2013). Is Inflation Targeting Dead? Central Banking after the Crisis. Vox eBook. Available at: http://www.voxeu.org/sites/default/files/file/P248\%20inflation\%20targeting\%282\%29.pdf

- Roger S. (2010). Inflation Targeting Turns 20. Finance \& Development, Vol. 47, No. 1, pp. 46-49.

- Roger, S., Restrepo J.E., Garcia C. (2009). Hybrid Inflation Targeting Regimes. Working Paper, No. 234, IMF.

- Schmidt-Hebbel K., Werner A. (2002). Inflation Targeting in Brazil, Chile, and Mexico: Performance, Credibility, and the Exchange Rate. Working Paper, No. 171, Central Bank Of Chile. https://doi.org/10.1353/eco.2002.0007

- Siregar R.Y., Goo S. (2009). Effectiveness and Commitment to Inflation Targeting Policy: Evidences from Indonesia and Thailand. Staff Paper No. 73, The South East Asian Central Banks, Research and Training Centre.

- Sotocinal N.R. (2010). Inflation targeting and interest rate rules: A characterization of the Philippine case. Discussion Paper, No. 1001, UP College of Business Administration.

- Stone M. (2003). Inflation Targeting Lite.Working Paper, No. 03-12, IMF. https://doi.org/10.5089/9781451842920.001

- Taguchi H., Kato C. (2010). Assessing the Performance of Inflation Targeting in East Asian economies. Macroeconomics Working Papers, No. 23078, East Asian Bureau of Economic Research.

- Tapsoba R. (2010). Does Inflation Targeting Improve Fiscal Discipline? An Empirical Investigation. Working Paper, No. 201020, CERDI.

- Topf B. (2005a). Dealing with Capital Inflows: The Israeli Experience. IMF Mimeo.

- Topf B. (2005b). Transition to Greater Exchange Rate Flexibility: The Israeli Experience. IMF Mimeo.

- Valdés J.A.B. (2007). The Conduct of Monetary Policy in Central America and Dominican Republic, in an Increasingly Globalised Environment. Available at:

http://www.secmca.org/INVESTIGACIONES_ECONOMICAS/InvestigacionesSECMCA/barbados.pdf.

- van der Merwe E.J. (2004). Inflation targeting in South Africa. Occasional Paper No. 19, South African Reserve Bank.

- Vavra D. (2005a). Czech experience with exit to float. IMF Mimeo.

- Vavra D. (2005b). The Czech Republic: Dealing with Capital Inflows. IMF Mimeo. 